\title{
Optimalisasi Saluran Distribusi dalam Pemasaran Jamur Tiram di UMKM Kabupaten Simalungun
}

\author{
Junaidi \\ Sekolah Tinggi Akuntansi dan Manajemen \\ Indonesia \\ junaidisiahaan@gmail.com \\ Debora Silvia Hutagalung \\ Sekolah Tinggi Akuntansi dan Manajemen Indonesia \\ deborahutagalung9@gmail.com \\ Roy Sahputra Saragih \\ Politeknik Bisnis Indonesia \\ roysahputra31@yahoo.com

\section{Merry} \\ Sekolah Tinggi Akuntansi dan Manajemen Indonesia \\ merryyae11@gmail.com
}

\begin{abstract}
Abstrak
This study aims to determine the constraints faced by farmers of oyster mushroom cultivators as well as manufacturers of processed oyster mushrooms products belonging to the Group of Women Farmers (KWT) UMKM Simalungun. Respondents intentionally set, including the chairman and members of the (KWT) UMKM Simalungun Group, PPL, and regular consumers from Pradnyagama autism children Foundation. Internal and external factors are identified and analyzed by SWOT analysis to determine some alternative strategies accordingly. Furthermore, alternative strategies are analyzed by QSPM to determine strategic priorities. The results of the research show that based on internal analysis, oyster mushroom processing business of UMKM Kabupaten Simalungun is on the average position in the harness strengths and weaknesses. The main strength of UMKM Kabupaten Simalungun is in the product variation. The main weakness of UMKM Kabupaten Simalungun is the selling price of the product. Based on the analysis of the external environment, oyster mushroom processing business of UMKM Kabupaten Simalungun is taking advantage of the opportunities to overcome the threats faced by UMKM Kabupaten Simalungun. The main opportunity UMKM Kabupaten Simalungun is rising customer demand. As for the main threat of UMKM Kabupaten Simalungun is rising a production cost. SWOT Analysis discover 6 alternative strategies namely: open opportunities for cooperation with other parties associated with the distribution of products, increased
\end{abstract}


sales promotion or dissemination of products information, to improve the appearance of products through improved packaging, looking for market information by using information technology, trying to maintain product quality and increase efficiency and effectiveness in marketing the product.

Kata Kunci marketing strategy, oyster mushrooms, SWOT, QSPM

\section{PENDAhuluan}

Komoditas pertanian memiliki sifat mudah rusak dan pada umumnya dikonsumsi dalam keadaan segar, sehingga diperlukan perlakuan khusus dalam penanganan pasca panen seperti pengolahan menjadi produk-produk olahan yang lebih tahan lama. Jamur tiram merupakan salah satu komoditas pertanian yang popular dewasa ini karena semakin banyaknya orang yang mengetahui dan sadar akan pentingnya nilai gizi yang terkandung dalam jamur tiram dan memiliki berbagai manfaat.Fakta tersebut merupakan hal positif, baik bagi upaya diversifikasi sumber pangan alternative maupun peluang bisnis bagi petani pembudidaya jamur tiram dan produsenb pengolahan produk olahan jamur tiram. Salah satu pembudidaya sekaligus produsen pengolah produk olahan jamur tiram adalah Kelompok Wanita Tani (KWT UMKM Simalungun),UMKM Kabupaten Simalungun mengolah berbagai macam produk olahan seperti kripik, krupuk, nugget, stick, abon dan berbagai macam produk olahan untuk kepentingan catering. Dalam kegiatannya UMKM Kabupaten Simalungun mulai mengalami kendala dalam kegiatan pemasaran yang masih terbatas dan hal ini menjadi kelemahan bagi UMKM Kabupaten Simalungun sehingga perlu dilakukan strategi untuk mengembangkan usahanya menjadi lebih baik dan tidak mengalami kerugian dalam kegiatannya. Menurut Suwarsono (1998), analisis lingkungan dimaksud untuk mencoba mengidentifikasi peluang yang perlu segera mendapatkan perhatian dan pada saat yang sama diarahkan untuk mengetahui ancaman yang perlu mendapatkan antisipasi. Analisis lingkungan internal memberikan gambaran bahwa perusahaan memiliki kekuatan (strengths) atau kelemahan (weakness) di bidang manajemen produksi, operasi pemasaran dan distribusi, organisasi sumber daya manusia, keuangan dan akuntansi. Adapun tujuan dilakukannya analisis internal adalah untuk mendapatkan faktor kekuatan yang akan digunakan dan faktor kelemahan yang akan diantisipasi keberadaannya. Analisis lingkungan eksternal adalah analisis yang tersusun dari sekumpulan- sekumpulan kekuatan-kekuatan yang timbul dan berada di luar jangkauan serta biasanya terlepas dari situasi operasional perusahaan. Menurut David (2003), faktor-faktor analisis lingkungan eksternal terdiri atas sosial, ekonomi, teknologi dan pemerintah, sedangkan menurut Kotler (1995), lingkungan eksternal terdiri atas kependudukan, ekonomi, fisik, teknologi, kebijakan dan peraturan pemerintah telah menjadi pertimbangan yang semakin penting bagi perusahaan atau organisasi akhir-akhir ini dalam merumuskan strategi guna mencapai sasaran yang diinginkan oleh perusahaan atau organisasi tersebut. Dari beberapa definisi di atas, maka dapat dirangkum bahwa 
lingkungan eksternal adalah suatu kekuatan yang berada di luar perusahaan dimana perusahaan tidak mempunyai pengaruh sama sekali terhadap (uncontrolable), sehingga perubahan-perubahan yang terjadi pada lingkungan ini akan mempengaruhi kinerja semua perusahaan dalam industri tersebut. Dari hasil analisis eksternal kemudian dilanjutkan dengan melakukan evaluasi untuk mengetahui apakah strategi yang digunakan selama ini memberikan respon terhadap peluang dan ancaman yang ada.

\section{METODE PENELITIAN}

Metode pengumpulan data yang dilakukan dalam penelitian ini adalah Library Research yaitu penelitain yang dilakukan dengan membaca publikasi yang berhubungan dengan penelitian dan Field Research yaitu pengumpulan data yang diperoleh secara langsung pada penelitian dengan metode observasi, wawancara, dan dokumentasi. Responden dalam penelitian ini adalah seluruh anggota UMKM Kabupaten Simalungun yang berjumlah 10 orang yang ditetapkan secara purposive. Untuk menentukan faktor internal dan faktor eksternal dilibatkan keseluruhan anggota UMKM Kabupaten Simalungun. Responden yang dipilih untuk pembobotan faktor-faktor internal dan eksternal yang digunakan pada matriks IFE, matriks EFE dan matriks IE adalah ketuadan sekretaris UMKM Kabupaten Simalungun, sedangkan untuk penentuan prioritas dan pembobotan strategi matriks QSPM adalah ketua UMKM Kabupaten Simalungun karena diasumsikan memiliki pengetahuan, kemampuan, dan kapasitas dalam pengembangan usaha pengolahan jamur tiram di masa depan. Untuk responden eksternal yang dipilih dalam pembobotan faktor internal dan eksternal adalah pimpinan dari Pradnyagama sebagai konsumen tetap dan satu orang petugas penyuluh lapangan dari Dinas Pertanian. Jadi keseluruhan responden berjumlah 12 orang. Analisis yang digunakan dalam penelitian ini adalah analisis lingkungan internal dan eksternal pemasaran. Formulasi strategi pada analisis lingkungan internal dan eksternal digunakan metode yang bersumber dari buku David (2003). Pada tahap pemasukan (The input stage) digunakan matriks IFE (Internal Factor Evaluation) dan EFE (External Factor Evalution). Dalam tahap pemaduan (The Matching Stage) digunakan alat analisis matrisk IE dan matriks SWOT. Matriks IE digunakan untuk menentukan posisi usaha. Matriks SWOT digunakan untuk menghasilkan strategi-strategi yang sesuai dengan kondisi internal dan eksternal pemasaran perusahaan. Tahap terakhir adalah tahap keputusan (The Decision Stage). Matriks QSPM digunakan dalam penentuan prioritas dari beberapa alternative strategi pemasaran yang dihasilkan dari tahap pemaduan.

\section{HASIL DAN PEMBAHASAN}

Keinginan KWT UMKM Kabupaten Simalungun untuk berkembang sangat kuat, hal ini ditunjukkan dengan mempersiapkan berbagai persyaratan untuk memperoleh izin dari Dinas Kesehatan yang bertujuan untuk memberikan rasa aman bagi konsumen. Berdasarkan hasil wawancara dengan ketua KWT UMKM Kabupaten Simalungun, sumber keuangan berasal dari iuran dari para anggota. Besarnya iuran ini tidak tentu jumlahnya karena disesuaikan dengan jumlah biaya yang akan dikeluarkan dalam kegiatan produksi. Namun demikian, iuran ini tidak dapat menjadi sumber keuangan 
selamanya bagi UMKM Kabupaten Simalungun, karena anggota tidak sanggup saat jumlah biaya produksi tinggi. Oleh karena itu diperlukan hubungan kerjasama dengan pihak luar untuk mendapatkan tambahan biaya dalam rangka peningkatan kualitas dan kuantitas produk. Analisis Lingkungan Internal Analisis lingkungan internal yang dilakukan yaitu terhadap faktor-faktor strategis internal yang terdiri dari kekuatan dan kelemahan dalam pemasaran produk olahan jamur tiram yang dilakukan oleh UMKM Kabupaten Simalungun dan adapun faktor-faktor strategis internal tersebut antara lain sebagai berikut.

\section{Kualitas Produk yang Baik}

Produk olahan jamur tiram ini bermanfaat bagi kesehatan karena bahan baku utamanya yaitu jamur tiram mengandung serat dan protein tinggi. Selain itu, jamur tiram juga berkhasiat untuk menyembuhkan penyakit seperti kolesterol dan baik untuk pelaku diet dan memelihara kesehatan karena kandungan karbohidratnya rendah kalori. Produk olahan UMKM Kabupaten Simalungun merupakan produk olahan yang ditangani secara baik dan menggunakan bahan-bahan khusus terbukti dengan adanya konsumen yang loyal dan sejauh ini tidak ada keluhan dari konsumen setelah dikonsumsi. Artinya produk olahan jamur tiram ini merupakan produk yang hygenis sehingga dapat dikatakan sebagai produk yang berkualitas baik.

Selain itu, adanya permintaan dari pasar modern yaitu Indomart menunjukkan produk tersebut berkualitas baik, karena tidak semua produk olahan dapat masuk ke pasar modern seperti Indomart. Pasar modern seperti Indomart biasanya memiliki ketentuan untuk suatu produk dapat masuk dan dipasarkan. Dengan demikian kondisi produk yang berkualitas baik ini menjadi kekuatan bagi UMKM Kabupaten Simalungun.

\section{Lokasi Produksi Strategis}

Lokasi pengolahan produk olahan jamur tiram berada di daerah yang strategis, yaitu berada di daerah pemukiman yang ramai di kawasan Monang-Maning yang membuka peluang banyaknya peminat jamur tiram dengan mudah mendapatkan hasil olahan jamur tiram. Hal ini merupakan faktor yang sangat esensial dalam proses pemasaran produk. Lokasi produksi UMKM Kabupaten Simalungun tidak jauh dari lokasi bahan baku berasal. Bahan baku dapat dengan mudah diperoleh dan tidak memerlukan biaya transportasi yang tinggi. Rendahnya biaya transportasi ini akan berpengaruh terhadap biaya produksi. Jika biaya produksi dapat ditekan, maka akan berdampak pada peningkatan keuntungan. Kondisi ini menjadi kekuatan bagi UMKM Kabupaten Simalungun.

\section{Bahan Baku Tidak Terbatas}

KWT UMKM Simalungun dapat memproduksi setiap jumlah pesanan yang diminta oleh konsumennya selama ini. Berapa pun besarnya jumlah pesanan tersebut dapat dipenuhinya. Hal ini dikarenakan segala kondisi produksi yang mendukung seperti bahan baku dan tenaga kerja yang memadai. Dengan demikian kegiatan produksi untuk 
mencapai kapasitas yang diinginkan dapat tercapai. Oleh karena itu, kondisi ini menjadi kekuatan bagi UMKM Kabupaten Simalungun.

\section{Jenis Produk Bervariasi}

Terdapat berbagai jenis produk olahan yang dihasilkan oleh UMKM Kabupaten Simalungun. Produk olahan tersebut yaituk kripik, kerupuk, nugget, dan produk masakan jadi seperti pepes, sate, siomay, sushi jamur dan lain-lain. Dengan demikian konsumen bisa memilih jenis olahan yang lebih disukai. Hal ini menjadi kekuatan bagi UMKM Kabupaten Simalungun dalam memasarkan produknya. Tidak semua orang menyukai jamur tiram meskipun dikatakan bahwa mengkonsumsinya baik untuk kesehatan. Dengan adanya pengolahan terhadap jamur tiram, maka jamur tiram akan lebih menarik untuk dikonsumsi mengingat manfaatnya yang cukup besar, apalagi UMKM Kabupaten Simalungun telah mampu mengolahnya menjadi berbagai jenis produk olahan jamur tiram, sehingga konsumen bisa lebih variatif dalam memilih.

\section{Dukungan Dari Komunitas Petani Jamur}

KWT UMKM Simalungun berada dalam lingkungan kawasan pembudidaya jamur tiram yang sering dijadikan tempat penelitian bagi pelajar atau mahasiswa perguruan tinggi di bidang pertanian. Selain itu, UMKM Kabupaten Simalungun juga mendapatkan pengarahan dan pembinaan dari Dinas Pertanian dan bekerjasama untuk penyaluran baglog. Di samping itu dukungan dari petani jamur di dalam dan luar daerah sangat bermanfaat untuk saling bertukar informasi dan teknik budidaya jamur. Selain itu, penelitian dan pelatihan ini mencakup kegiatan pengolahan produk, sampai pada pemasaran produk, sehingga keberadaanya sangat berpengaruh positif dalam pengembangan kegiatan yang dilakukan oleh kelompok tani. Hal tersebut membuat UMKM Kabupaten Simalungun dapat meningkatkan keterampilannya. Dengan peningkatan keterampilan ini diharapkan UMKM Kabupaten Simalungun mampu memperbaiki produksinya sampai pada pemasaran produknya sehingga lebih efektif dan efisien. Dengan demikian, kondisi ini menjadi kekuatan bagi UMKM Kabupaten Simalungun dalam melakukan kegiatan pengolahannya yang selanjutnya berdampak pada kegiatan pemasaran.

\section{Kemasan Produk Kurang Memadai}

Kemasan yang masih sangat sederhana menunjukkan bahwa belum diterapkannnya teknologi pengemasan. Produk yang telah memiliki kualitas baik sebaiknya ditunjang dengan kemasan yang menarik. Kondisi ini menjadi kelemahan bagi UMKM Kabupaten Simalungun dalam memasarkan produknya dikarenakan tampilan produk menjadi kurang menarik. Padahal bagaimana produk itu dikemas akan sangat menentukan pemasaran produk. Kemasan produk pada akhirnya akan menentukan besarnya harga jual produk tersebut. Akibat lain karena belum menggunakan teknologi pengemasan yang baik yaitu berpengaruh terhadap umur simpan produk yang lebih pendek. Hal ini tentu akan menimbulkan kerugian bagi UMKM Kabupaten Simalungun jika produk tidak cepat terjual. 


\section{Merek Produk Kurang dikenal}

Sampai saat ini produk hasil olahan KWT UMKM Kabupaten Simalungun belum mempunyai merek dagang. Dengan demikian konsumen belum mengenal dengan baik produk olahan ini. Merek yang digunakan juga sering diganti-ganti dalam beberapa kurun waktu seperti jamur Rezza, jamur enak dan lain-lain. Seharusnya dipilih dan ditetapkan satu nama yang akan digunakan untuk mempermudah mengenali produk yang beredar dipasaran. Hal ini menjadi kelemahan bagi UMKM Kabupaten Simalungun dalam memasarkan produknya.

\section{Analisis Lingkungan Eksternal}

Analisis lingkungan eksternal yang dilakukan yaitu terhadap faktor-faktor strategis eksternal yang terdiri dari peluang dan ancaman dalam pemasaran produk olahan jamur tiram yang dilakukan oleh UMKM Kabupaten Simalungun. Adapun faktor-faktor strategis eksternal tersebut antara lain sebagai berikut.

\section{Meningkatnya Permintaan Pelanggan}

Dengan memiliki kualitas produk yang baik maka konsumen akan menjadi loyal dan percaya akan kualitas dan kesehatan produk yang dihasilkan UMKM Kabupaten Simalungun. Ini dibuktikan dengan meningkatnya permintaan konsumen terutama pelanggan tetap setiap tahunnya. Permintaan dari produsen dan pemesanan secara langsungpun semakin meningkat, ini menjadi peluang bagi UMKM Kabupaten Simalungun dalam mengembangkan usahanya.

\section{Perkembangan Teknologi}

Adanya perkembangan teknologi semakin memudahkan dalam kegiatan produksi. Contohnya dalam hal penggunaan peralatan seperti adanya juicer, blender, slicer, dan sealer akan lebih memudahkan dalam proses produksi. Kegiatan produksi yang lebih mudah dapat membantu tahap selanjutnya yaitu pemasaran produk.

Selain adanya peralatan yang dapat memudahkan kegiatan produksi, kemajuan teknologi juga memudahkan dalam pencarian informasi yang berkenaan dengan kegiatan pemasaran produk. Misalnya pencarian informasi melalui media cetak, media elektronik, dan internet. Di samping itu, kemajuan dalam sektor transportasi juga memudahkan dalam memasarkan produk. Oleh karena itu, adanya perkembangan teknologi produksi dan teknologi informasi menjadi peluang bagi UMKM Kabupaten Simalungun dalam memasarkan produk.

\section{Dukungan Pemerintah Pada UKM}

Pemerintah Daerah yang turut memberikan dukungan kepada kegiatan usaha UMKM Kabupaten Simalungun ini adalah Dinas Pertanian (Dispertan) dan Dinas Perindustrian dan Perdagangan (Disperindag). Dispertan memberikan dukungan dalam bentuk pemberian pengarahan dan pembinaan kepada UMKM Kabupaten Simalungun dalam hal pembudidayaan jamur tiram dan segala bentuk kegiatannya. Disperindag memberikan dukungan dalam bentuk pemberian pelatihan dalam kegiatan produksi sampai pemasaran 
produk serta pemberian bantuan peralatan dan informasi-informasi mengenai seminar yang dapat menambah keterampilan anggota UMKM Simalungun dalam menjalankan usahanya sebagai industri rumah tangga yang tergolong dalam usaha kecil menengah.

\section{Trend Gaya Hidup Sehat Masyarakat}

Saat ini konsumen semakin cerdas dalam memilih suatu produk. Trend healthy life telah menjadi semakin memasyarakat. Konsumen cenderung lebih memilih produk yang sehat dan aman untuk dikonsumsi. Salah satu indikator produk yang aman adalah tanpa bahan pengawet. Produk olahan UMKM Kabupaten Simalungun ini diproduksi tanpa menggunakan bahan pengawet. Dengan demikian konsumen akan merasa aman untuk mengkonsumsi produk ini. Selain itu, kandungan gizi dan manfaat yang terdapat dalam jamur tiram pun akan menjadi pilihan makanan yang baik untuk dikosumsi oleh semua umur. Kondisi ini akan menjadi peluang bagi UMKM Kabupaten Simalungun dalam memasarkan produknya.

\section{Matriks IE}

Hasil pemetaan matriks IE di atas, menunjukkan bahwa UMKM Kabupaten Simalungun berada pada sel V. Penetrasi pasar merupakan strategi pemasaran terbaik yang dapat dilakukan oleh UMKM Kabupaten Simalungun dalam memasarkan produk olahan jamur tiram.

Strategi penetrasi pasar merupakan strategi pemasaran yang berusaha meningkatkan pangsa pasar untuk produk yang sudah ada di pasar melalui peningkatan usaha pemasaran. Strategi ini perlu dilakukan mengingat daerah pemasaran UMKM Kabupaten Simalungun yang masih terbatas dan dilakukan oleh suatu perusahaan untuk meningkatkan penjualan atas produk dan pasar yang telah tersedia melalui usaha-usaha pemasaran yang lebih agresif dengan menitikberatkan bauran pemasaran sebagai tolak ukurnya dalam tindakan nyata sebagai usaha untuk menjalankan pemasaran secara efektif. Secara umum penetrasi pasar dapat dibedakan atas tiga bentuk yaitu: Pertama, perusahaan dapat mencoba merangsang konsumen mereka untuk meningkatkan pembelian. Pembelian dapat diuraikan sebagai fungsi dari frekuensi pembelian dikalikan dengan jumlah pembelian yang dilakukan. Suatu perusahaan dapat mendorong konsumennya untuk membeli lebih sering sekaligus untuk membeli lebih banyak setiap pembelian. Promosi harga, iklan, publisitas, dan perluasan jaringan distribusi sangatlah membantu kegiatan ini. Secara lebih mendasar, perusahaan dapat mempertimbangkan kesempatan-kesempatan untuk meningkatkan tingkat konsumsi yang ada, yang merupakan dasar dari tingkat pembelian yang dihadapi. Tingkat konsumsi adalah fungsi dari penggunaan produk dikalikan dengan jumlah yang digunakan atau dikonsumsi pada setiap kali penggunaan konsumsi. Hal yang dapat dilakukan oleh KWT UMKM Kabupaten Simalungun dalam hal ini adalah lebih gencar melakukan promosi dengan cara memberikan potongan harga atau harga khusus kepada pelanggan tetap dan konsumen lainnya apabila melakukan pembelian dalam jumlah besar, hal ini akan merangsang konsumen untuk meningkatkan pembeliannya. Kedua, perusahaan dapat meningkatkan usahanya dengan menarik atau mempengaruhi konsumen saingan. Sarana yang digunakan tidak berbeda hanya pada sasaran atau target 
yang akan dicapai, yaitu pada konsumen saingan. Hal yang dapat dilakukan oleh UMKM Kabupaten Simalungun dalam hal ini adalah lebih gencar melakukan promosi atas keunggulan yang dimiliki oleh UMKM Kabupaten Simalungun dalam hal produk yang dihasilkan, seperti mencantumkan manfaat dan komponen - komnponen berkualitas yang digunakan dalam produk olahan yang dihasilkan sehingga konsumen menjadi beralih ke produk yang dihasilkan oleh UMKM Kabupaten Simalungun. Ketiga, perusahaan meningkatkan usahanya dengan menarik yang bukan pemakai (nonusers) atau calon konsumen yang berada dalam lingkungan pasarnya. Hal yang dapat dilakukan oleh UMKM Kabupaten Simalungun dalam hal ini adalah membuat variasi harga yang lebih terjangkau masyarakat umum dengan menggunakan bahan - bahan yang umum digunakan dan tidak hanya terbatas pada konsumen tetap yang menggunakan bahan - bahan khusus dengan harga khusus sehingga usaha pengolahan ini dapat berkembang lebih baik.

\section{Matriks SWOT}

Strategi pemasaran dari hasil Matriks SWOT dijabarkan sebagai berikut.

a. Membuka peluang kerja sama dengan pihak lain terkait dengan pendistribusian produk. (S1, S3, S4, S5, O1, O3, O5). Strategi ini terkait dengan strategi bauran pemasaran tentang distribusi produk. Kerja sama yang dapat dilakukan misalnya dengan toko-toko yang menjual makanan oleh-oleh di Kabupaten Simalungun. UMKM Kabupaten Simalungun dapat menitipkan produk olahannya di toko-toko tersebut untuk kemudian dijual dengan sistem konsinyasi. Kerja sama lainnya dapat dilakukan dengan tempat-tempat wisata di wilayah Kabupaten Simalungun. UMKM Kabupaten Simalungun dapat menjual produk olahannya tersebut dengan membuka lapak setiap akhir pekan atau musim liburan sekolah. Dua bentuk kerja sama dengan pihak lain tersebut dapat membantu UMKM Kabupaten Simalungun dalam pendistribusian produk. Dengan pendistribusian produk ke dua tempat yang berbeda diharapkan penjualan produk akan meningkat dan masyarakat akan lebih mengenal produk olahan jamur yang diproduksi oleh UMKM Kabupaten Simalungun.

b. Peningkatan promosi penjualan atau penyebaran informasi produk (W2, W3, W5, O2, O3, O4, O5). Strategi ini terkait dengan strategi bauran pemasaran tentang promosi produk. Promosi terhadap produk yang dilakukan saat ini belum optimal dilakukan oleh KWT UMKM Kabupaten Simalungun untuk memasarkan produknya. Oleh karena itu, strategi promosi lainnya perlu dilakukan guna lebih mengenalkan produk terhadap masyarakat. Promosi yang dapat dilakukan yaitu melalui pemasaran langsung dengan pemberian contoh makanan untuk dicoba langsung oleh konsumen. Dengan begitu diharapkan konsumen akan tertarik untuk mencoba produk tersebut dan kemungkinan untuk melakukan pembelian. Pemasaran langsung dirasa paling efektif karena UMKM Kabupaten Simalungun dapat langsung berhubungan secara intensif dengan konsumen dalam mempengaruhi pembelian. 
c. Memperbaiki tampilan produk melalui perbaikan kemasan (W1, O2, O3). Strategi ini terkait dengan strategi bauran pemasaran tentang produk. Kemasan produk kripik, krupuk dan nugget yang kurang menarik saat ini perlu diperbaiki, sehingga dapat meningkatkan harga jual produk tersebut. Dengan kemasan produk krupuk, kripik dan nugget jamur tiram yang menarik,UMKM Kabupaten Simalungun juga dapat memasarkan produknya tersebut di pasar modern (Indomart) seperti yang telah diminta oleh Indomart selama ini. Oleh karena itu, memperbaiki kemasan ini menjadi penting untuk dilakukan karena dapat meningkatkan harga jual produk dan dapat memperluas daerah pemasaran yang tentunya akan berdampak pada peningkatan penjualan produk. Saat ini harga kripik per $1 \mathrm{~kg}$ yaitu $\mathrm{Rp} 60.000$ per pack, jika kemasan tersebut diperbaiki maka dapat meningkatkan harga kripik jamur tiram tersebut.

d. Mencari informasi pasar dengan penggunaan teknologi informasi (W3, W5, O2, O3, O5). Strategi ini terkait dengan strategi bauran pemasaran tentang distribusi produk. Daerah pemasaran UMKM Kabupaten Simalungun saat ini masih sangat terbatas yaitu didaerah Raya dan Perdagangan. Pencarian informasi pasar tentang daerah pemasaran lain yang tepat untuk memasarkan produk perlu dilakukan. Dengan penggunaan teknologi informasi seperti media cetak dan media elektronik dapat membantu UMKM Kabupaten Simalungun dalam memperluas daerah pemasaraannya. Informasi yang diperoleh dapat berupa informasi mengenai jangkauan pasar. Hal ini perlu dilakukan karena semakin luas daerah pemasaran yang dimiliki, maka akan semakin meningkatkan penjualan produk.

e. Berusaha mempertahankan kualitas produk (S1, S4, S5, T4, T5). Strategi ini terkait dengan strategi bauran pemasaran tentang harga produk. Produk olahan jamur tiram terutama kripik dan nugget yang telah memiliki kualitas produk yang baik ini perlu dipertahankan. Dengan kualitas produk kripik dan nugget jamur tiram yang tetap dapat dilakukan.

\section{Matriks QSPM}

Tahap terakhir dalam perumusan strategi pemasaran adalah tahap keputusan dengan menggunakan Matriks QSPM. Hasil kuesioner yang diisi oleh responden mengenai kemenarikan alternatif strategi pemasaran produk olahan jamur tiram UMKM Kabupaten Simalungun. Berdasarkan Matriks QSPM menunjukkan bahwa strategi 3 mendapat total nilai kemenarikan terbesar yaitu 7,628 yaitu memperbaiki tampilan produk melalui perbaikan kemasan terutama kemasan untuk produk kripik dan nugget jamur tiram. Adapun hasil perhitungan matriks QSPM yaitu perkalian antara rata-rata bobot faktorfaktor strategis internal dan eksternal dengan nilai daya tarik (AS). urutan pemilihan strategi berdasarkan angka kemenarikannya adalah sebagai berikut.

1. Memperbaiki tampilan produk melalui perbaikan kemasan.

2. Membuka peluang kerjasama dengan pihak lain terkait dengan pendistribusian produk. 
3. Mencari informasi pasar dengan penggunaan teknologi informasi.

4. Peningkatan promosi penjualan atau penyebaran informasi produk.

5. Meningkatkan efisiensi dan efektivitas dalam pemasaran produk.

6. Berusaha mempertahankan kualitas produk.

Strategi tiga menjadi strategi pemasaran prioritas dikarenakan perbaikan tampilan produk melalui perbaikan kemasan adalah merupakan strategi pemasaran yang paling mungkin untuk dilakukan oleh UMKM Kabupaten Simalungun saat ini. Dengan memperbaiki kemasan produk, maka peluang kerja sama dengan pihak lain terkait dengan masalah distribusi akan lebih mudah untuk dilakukan. Selain itu, pencarian informasi untuk memperluas daerah pemasaran yang tepat juga akan lebih terarah karena UMKM Kabupaten Simalungun telah memiliki produk yang berkualitas dengan tampilan produk yang sudah menarik. Artinya strategi pemasaran yang lain dapat dilaksanakan setelah strategi tiga dilaksanakan.

\section{KESIMPULAN}

1. Berdasarkan analisis lingkungan internal pemasaran, usaha pengolahan jamur tiram UMKM Kabupaten Simalungun berada pada posisi sedang dalam memanfaatkan kekuatan dan kelemahan usaha yang ada. Kekuatan utama UMKM Kabupaten Simalungun terdapat pada variasi produk. Adapun yang menjadi kelemahan utama UMKM Kabupaten Simalungun adalah harga jual produk yang tinggi. Berdasarkan analisis lingkungan eksternal pemasaran, usaha pengolahan jamur tiram UMKM Kabupaten Simalungun berada pada posisi sedang dalam memanfaatkan peluang untuk mengatasi ancaman yang dihadapi UMKM Kabupaten Simalungun. Peluang utama UMKM Kabupaten Simalungun yaitu meningkatnya permintaan pelanggan. Adapun yang menjadi ancaman utama UMKM Kabupaten Simalungun adalah biaya produksi yang meningkat.

2. Hasil perumusan strategi pemasaran berdasarkan Matriks IE,UMKM Kabupaten Simalungun berada pada kelompok usaha hold and maintain strategy (strategi mempertahankan dan memelihara), sehingga strategi yang dapat dilakukan adalah penetrasi pasar dengan cara meningkatkan penjualan atas produk dan pasar yang telah tersedia melalui usaha -usaha pemasaran yang lebih agresif seperti melakukan promosi secara langsung dan melalui media sosial. Dengan demikian diperoleh enam strategi aplikatif dari strategi penetrasi pasar yang merupakan hasil dari Matriks SWOT.

3. Berdasarkan Matriks QSPM, diperoleh strategi pemasaran prioritas usaha pengolahan jamur tiramUMKM Kabupaten Simalungun yaitu memperbaiki tampilan produk melalui perbaikan kemasan.

\section{REFERENSI}

[1] Anindita, R. 2004. Pemasaran Hasil Pertanian. Surabaya: Papyrus.

[2] Aryawan, G. 2007. Studi Kelayakan Usaha Budidaya jamur Tiram di Kabupaten

[3] Muhammad, S. 2002. Manajemen Strategik.Konsep dan Kasus.Edisi ketiga. Yogyakarta: UPP AMP YKPN 
Jurnal Ekonomi \& Ekonomi Syariah Vol 3 No 1, Januari 2020

E-ISSN : 2599-3410 | P-ISSN : 2614-3259

DOI : https://doi.org/10.36778/jesya.v3i1.125

[4] Tabanan. (Tesis). Universitas Udayana.

[5] Wiardani, I. 2010. Budi Daya Jamur Konsumsi. Yogyakarta: Lily Publisher

[6] Rangkuti, F. 2000. Analisis SWOT Teknik Membedah Kasus Bisnis. Jakarta: Gramedia. Rukmana, Rahmat

[7] Kotler, Philip dan Armstrong. 2000. Manajemen Pemasaran Terjemahan Jakarta : Gramedia Pustaka Utama

[8] David. 2003. Manajemen Pemasaran. Jakarta: Gramedia.

[9] Suwarsono (1998), Manajemen Strategik: Konsep dan Kasus, Edisi Revisi, Cetakan 2, Yogyakarta : UPP AMP YKPN 